\title{
Kinetic studies on anaerobic co-digestion of ultrasonic disintegrated feed and biomass and its effect substantiated by microcalorimetry
}

\author{
R. Priyadarshini $\cdot$ L. Vaishnavi $\cdot$ D. Murugan · \\ M. Sivarajan · A. Sivasamy • P. Saravanan • \\ N. Balasubramanian $\cdot$ C. Lajapathi Rai
}

Received: 18 February 2014/Revised: 26 August 2014/Accepted: 11 October 2014/Published online: 21 October 2014

(C) Islamic Azad University (IAU) 2014

\begin{abstract}
Studies were carried out on anaerobic codigestion of primary and secondary excess sludge obtained from tannery effluent treatment plant. Anaerobic biomass collected from a treatment plant was used as the source of micro-organisms. The optimum feed to micro-organism ratio was evaluated as 0.7 on the basis of volatile solids reduction cum gas production. Both feed and anaerobic biomass were subjected to ultrasonic pre-treatment in order to enhance the digestion process. Experiments carried out on batch mode showed significant increase in the gas production for pre-treated feed and biomass. Optimum pretreatment durations were evaluated as $5 \mathrm{~min}$ for feed and $3 \mathrm{~min}$ for anaerobic biomass. Heat flow analyses of the anaerobic biomass using isothermal microcalorimetry throw light on different stages of digestion process. The effect of ultrasonic pre-treatment on anaerobic biomass was also substantiated using this technique. The heat energy released by pre-treated and untreated anaerobic biomass was evaluated as 16.3 and $7.6 \mathrm{~kJ} / \mathrm{kg}$, respectively. Kinetic analysis revealed that the overall rate constant of digestion process increased by 1.5 times due to pre-treatment. However, the initial lag time increased by about $20 \%$ for the optimally pre-treated sample compared to
\end{abstract}

R. Priyadarshini - L. Vaishnavi - D. Murugan - M. Sivarajan · A. Sivasamy · C. L. Rai ( $₫)$

Chemical Engineering Division, Central Leather Research Institute (CSIR), Adyar, Chennai 600 020, India

e-mail: clrai@hotmail.com

P. Saravanan

Leather Processing Division, Central Leather Research Institute (CSIR), Adyar, Chennai 600 020, India

N. Balasubramanian

Department of Chemical Engineering, A. C. College of

Technology, Anna University, Guindy, Chennai 600 025, India untreated sample. Modified Gompertz equation was used to model, and the parameters were evaluated. The significance of this work lies on energy production (bio gas) and at the same time increasing the maintenance metabolism rate thereby minimizing excess sludge biomass generation.

Keywords Activated sludge - Anaerobic digestion . Isothermal microcalorimetry · Ultrasonic pre-treatment

\section{Introduction}

Nearly 2,000 tanneries are located throughout India with a total processing capacity of about 700,000 tonnes of hides/ skins per annum (Balakameswari et al. 2010). Waste-activated sludge or excess sludge is an unavoidable by-product generated in common effluent treatment plants (CETPs) as a consequence of treating tannery wastewater. On an average of about 50-60 kg of primary sludge and $15-20 \mathrm{~kg}$ of secondary sludge are produced per ton of raw hides/ skins (NEERI Report 1997). It has been observed that $60-65 \%$ of the sludge generated from tanneries is predominantly organic and putrescible in nature. It contains mostly micro-organisms and biodegradable organic compounds such as proteins, carbohydrates, fats and mineral parts (Saravanabhavan et al. 2004). Disposal of sludge is a major concern in terms of environmental protection (Balakameswari et al. 2010). Sludge management requires about $30-40 \%$ of the capital cost and approximately $50-55 \%$ of operation and maintenance cost of the tannery wastewater treatment (Weemaes and Verstraete 1998; Appels et al. 2008). Therefore, the sludge needs to be treated in order to reduce its associated volume and also to reduce the associated health problems. Large quantities of sludge can be better processed using appropriate biological 
techniques to stabilize the wastes and to produce biogas (Braguglia et al. 2012). Anaerobic digestion is one such technique which can be used to reduce the volume of sludge and also for generation of biogas.

\section{Anaerobic co-digestion of waste-activated sludge}

Details about biological aspects of the anaerobic codigestion process have been reported in exclusive literature on the subject (Stronach et al. 1986; Gerardi 2003; Deublein and Steinhauser 2008). Anaerobic co-digestion of waste-activated sludge or any organic material is a complex process which essentially consists of following steps in sequence viz. hydrolysis, acidogenesis, acetogenesis and methanogenesis. This process requires strict anaerobic conditions to proceed (oxidation reduction potential of less than $-200 \mathrm{mV}$ ) (Appels et al. 2008). Hydrolysis is considered as the rate-limiting step in the digestion process (Safari et al. 2011). During the above step, the insoluble organic material and high molecular weight compounds such as lipids, polysaccharides, proteins and nucleic acids are degraded into soluble organic substances such as amino acids and fatty acids. The products of hydrolysis are further converted into volatile fatty acids, ammonia and carbon dioxide during the acidogenesis step by acidogenic bacteria. Higher organic acids and alcohols produced during acidogenesis are further digested during acetogenesis by acetogens to produce mainly acetic acid, $\mathrm{CO}_{2}$ and $\mathrm{H}_{2}$. Methane is produced by methanogenic bacteria in final step called methanogenesis. Temperature plays a major role in the digestion process. Digestion can take place at moderate temperatures $\left(30-38^{\circ} \mathrm{C}\right)$ as well as at relatively higher temperatures $\left(50-57^{\circ} \mathrm{C}\right)$. The former is mesophilic digestion and the latter one is thermophilic digestion, and each of these digestion methods has their own merits and demerits (Amani et al. 2011).

\section{Need for pre-treatment operations}

Technological developments in the area of bioreactor design for the treatment of solid organic wastes have increased the interest in anaerobic digestion (Zhang et al. 2012; Khalid et al. 2011; Selvamurugan et al. 2012). However, due to low biodegradability and high solid content, sludge requires long retention time of about 20-30 days to reach even moderate efficiencies of 30-50 \% (Pavlostathis and Gossett 1986). Therefore, in order to reduce the residence time and to enhance volume reduction/gas generation, appropriate pre-treatment techniques should be considered prior to the digestion process. Moreover, most of the organics trapped within the microbial cell membrane contains glycan strands cross-linked by peptide chains which are resistant to biodegradation
(Weemaes and Verstraete 1998). Pre-treatment unit operations could improve the digestion efficiency by converting slowly degradable particulates into readily degradable compounds through pre-treatment mainly by disintegration.

Pre-treatment techniques such as oxidative, mechanical, thermo-chemical, microwave, biological have been investigated by researchers on waste-activated sludge (Weemaes et al. 2000; Carrère et al. 2010; Nagai et al. 2012; Uma Rani et al. 2013; Uan et al. 2013; Merrylin et al. 2013; Kavitha et al. 2014; Lakshmi et al. 2014). Wang et al. (1999) studied the effects of ultrasonic pre-treatment on the solubilization of waste-activated sludge and on methane generation. Ultrasonic pre-treatment increased the methane production by $64 \%$ as compared with the untreated sludge. Lin et al. (2009) and Uma Rani et al. (2012, 2014) employed alkali-mechanical combined pre-treatment process to improve anaerobic co-digestion. Recently, microaeration has been reported (Lim and Wang 2013) as an alternative pre-treatment method to enhance hydrolysis during the anaerobic co-digestion of brown water and food waste.

All these reported works have studied the influence of pre-treatment on feed (sludge). However, the effect of pretreatment on anaerobic biomass is yet to be studied. Diligent disintegration of anaerobic biomass by techniques such as ultrasonic pre-treatment would enhance the microbial activity due to increase in the maintenance metabolism. Therefore, the purpose of this work was to study the influence of ultrasonic pre-treatment on anaerobic biomass as well as feed sludge followed by anaerobic digestion. The feed sludge refers to the mixture of primary and secondary sludge generated from tannery wastewater treatment plant along with cow dung which is a cosubstrate.

\section{Biological processes and heat measurement}

Heat production in biological systems and processes has been discussed in detail in the literature (Battley 1987; Gustafsson 1991; Alklint et al. 2004). In all these studies, calorimetry was used as an analytical tool to gain insight into the biological processes. With recent advances in calorimetry such as the development of highly flexible and ultrasensitive calorimetric instruments, the focus is on to use these techniques to obtain kinetic as well as analytical information from biological process. Any biological/biochemical process is associated with a definite amount of heat change. Conversely, precise measurement of magnitude and profile of heat change curves for the system could provide information about the microbial growth and associated process. This underlying principle has been utilized in the present study by employing microcalorimetry 
technique for the precise measurement of ultrasonic pretreatment effect on anaerobic biomass. Although the optimal digestion temperature lies around $35{ }^{\circ} \mathrm{C}$ for mesophilic treatment, the operating temperature in this study was maintained at standard temperature of $25{ }^{\circ} \mathrm{C}$ for both control (untreated) as well as experiment (pre-treated). The main objective was to compare and analyse the heat production rate for both the cases at a constant temperature. Similar comparison study at $25{ }^{\circ} \mathrm{C}$ has been carried out by Alklint et al. (2004) for studying the shelf life of fruit juices.

Therefore, the objectives of this work were as follows.

- To study the effect of individual feeds and mixed feed (primary sludge, secondary sludge and cow dung) with biomass for anaerobic digestion

- To select an optimum F/M ratio required for efficient digestion

- To study the disintegrability studies on feed

- To select the optimum pre-treatment durations for feed and biomass based on gas production

- To study the effect of ultrasonic pre-treatment/disintegration on anaerobic biomass by isothermal microcalorimetry

- To model the sludge digestion process and to determine the kinetic parameters

\section{Materials and methods}

\section{Materials}

\section{Substrate}

Primary sludge and secondary sludge from tannery effluent treatment plant were used as the substrates. These sludge samples were collected from tannery common effluent treatment plant, Ranipet, Tamilnadu, India.

\section{Co-substrate}

Cow dung collected from a nearby farmhouse was used as a co-substrate in the studies. It helps to reduce the toxic effects present (if any) in the primary sludge. The use of co-substrates during anaerobic co-digestion has been reported to improve the gas yield from anaerobic digesters. This is due to the positive synergisms established in the digestion medium and the supply of missing nutrients by the co-substrates. Sometimes the use of co-substrates may also be required to maintain moisture content of the digester feed (Alvarez et al. 2000).
Source of micro-organisms

Anaerobic biomass collected from an anaerobic treatment plant near Chennai, India, was used as the source of microorganisms.

\section{Chemicals}

Analytical grade reagents such as potassium dichromate, mercuric sulphate, concentrated sulphuric acid and potassium hydrogen phthalate procured from S D Fine Chemicals Limited, Mumbai, were used in the study.

Methods

\section{Sample stabilization and characterization}

Primary, secondary sludge samples and cow dung were stabilized and stored at $4-5{ }^{\circ} \mathrm{C}$ to arrest any degradation. Anaerobic biomass was sieved using a $2 \times 2 \mathrm{~mm}$ mesh sieve to remove large lumps and was stored under anaerobic conditions. Little quantities of oil cake and cow dung were mixed with anaerobic biomass to prevent starvation of the micro-organism. Sludge samples were characterized according to the methods described in Standard Methods for Examination of Water and Wastewater (APHA 1998). $\mathrm{pH}$ was measured using ELICO LI120 pH meter, and soluble chemical oxygen demand (SCOD) was evaluated by closed reflux, colorimetric method (5220D). UV2101PC, Shimadzu UV-Vis scanning spectrophotometer was used in the study. Total and volatile solids were determined by $2540 \mathrm{G}$ method. The characteristics of primary, secondary sludge and anaerobic biomass are given in Table 1.

\section{CHN analysis}

Earlier studies have reported the optimum feed to microorganism ratio and the corresponding carbon to nitrogen ratio (C:N) along with it (Navaneethan 2007). In this study, $\mathrm{C} / \mathrm{N}$ ratio was determined by $\mathrm{CHN}$ analysis using the Elemental Analyzer, Euro EA 3000, Euro Vector, Italy. The sample was weighed in tin or silver capsules and introduced into the combustion reactor where the sample was combusted with proper amounts of oxygen and catalysts. Products of combustion reaction $\left(\mathrm{CO}_{2}, \mathrm{H}_{2} \mathrm{O}, \mathrm{NO}_{\mathrm{X}}\right.$ and $\mathrm{SO}_{2}$ ) were carried by helium flow to the copper reactor where excess oxygen was consumed and $\mathrm{NO}_{\mathrm{X}}$ products were converted to $\mathrm{N}_{2}$. The products were carried through a gas chromatography column that separated the combustion gases and was detected by a thermal conductivity detector. 
Table 1 Characterization of feed and anaerobic biomass

\begin{tabular}{lllllll}
\hline S. No & Parameters & Unit & Primary sludge & Secondary sludge & Cow dung & Anaerobic biomass \\
\hline 1 & $\mathrm{pH}$ & - & $8.0-8.8$ & $7.1-7.9$ & $5.9-7.3$ & $5.2-6.9$ \\
2 & Soluble COD & $\mathrm{g} / \mathrm{L}$ & $1.25-1.4$ & $1.1-1.3$ & - & - \\
3 & Total solids & $\mathrm{g} / \mathrm{L}$ & 65.3 & 48.3 & 74.6 & 77.6 \\
4 & Volatile solids & $\mathrm{g} / \mathrm{L}$ & 24.9 & 19.7 & 59.1 & 52 \\
\hline
\end{tabular}

\section{Ultrasonic pre-treatment}

The sludge samples were pre-treated by ultrasonic homogenizer (Sonics vibra cell, USA). The frequency of $20 \mathrm{kHz}$ turned out to be the most efficient and economical (Zielewicz and Sorys 2008). Transducer and Sonotrode form the major components of the instrument. Sonotrode is made up of a booster and a horn. The booster is a mechanical amplifier that helps to increase the amplitude generated by the converter. The horn or the probe is a specially designed tool that can deliver ultrasonic energy to the sludge (Navaneethan 2007). Schematic of the ultrasonic sludge disintegration set-up is shown in Fig. 1a. Pretreatment of anaerobic biomass was done with multi-probe (4 horns) throughout the study. The important operating parameters considered during the study were sonication time, sludge volume, TS content of the samples and power input. Hydro-mechanical shear forces produced during ultrasonic pre-treatment were expected to disintegrate the sludge flocs and rupture the cell wall (Tiehm et al. 2001). Pre-treatment of anaerobic biomass (micro-organisms) was carried out to increase the activity of micro-organisms.

The specific energy input provides information about the energy required to achieve a certain degree of disintegration which can be calculated using the following equation.

$\mathrm{SE}=\frac{P t}{\mathrm{TS} \times V}$

where $S E$ is specific energy in $\mathrm{kJ} / \mathrm{kg}, P$ is the ultrasonic power in $\mathrm{kW}, t$ is the sonication time in seconds, $V$ is the volume of sludge in litres and TS is the total solids in $\mathrm{kg} / \mathrm{L}$.

\section{Microcalorimetry studies}

In this study, microcalorimetry technique has been employed successfully to quantify the effect of ultrasonic pre-treatment on anaerobic biomass precisely. Microcalorimetric experiments were carried out using TAM III instrument, supplied by TA instruments, USA. This instrument is equipped with a high-precision temperature controller that could control temperature to within $0.0001{ }^{\circ} \mathrm{C}$. Batch experiments were performed under standard mode with $4 \mathrm{~mL}$ glass ampoules at $25^{\circ} \mathrm{C}$. Untreated fresh anaerobic biomass taken from the digester was used as the control sample. Ultrasonic pre-treated anaerobic biomass (of the same batch as the control sample) was used as the experiment sample. Experiments involving both untreated and treated samples took more than $40 \mathrm{~h}$ each. Heat flow profiles of the control and the pre-treated samples were compared, and the energy released was computed using the following equation.

$E=\int_{t_{0}}^{t_{\mathrm{f}}} Q \cdot \mathrm{d} t$

Anaerobic digester set-up and gas collection

Schematic of the typical anaerobic digester set-up is shown in Fig. 1b. Experiments were carried out in triplicates for both control and experiment using identical digesters each with working volume of $1 \mathrm{~L}$. These digesters were capped with butyl rubber stoppers and sealed with aluminium caps in order to make them air tight. Gas generation from the digesters was measured by Mariotte principle water displacement method reported elsewhere (Itodo et al. 1992). The digesters were manually shaken for every $12 \mathrm{~h}$, and the gas generation was measured at an interval of $24 \mathrm{~h}$.

\section{Modelling of gas production}

Experimental gas production data obtained during the anaerobic digestion process were simulated using modified Gompertz model, and the parameters were estimated using data analysis software CurveExpert Professional 2.0.3.

\section{Results and discussion}

Effect of feed on gas production

Experiments were conducted to study the effect of individual feeds (primary sludge, secondary sludge and cow dung) and mixed feed with anaerobic biomass for gas production. Individual and mixture of feeds (on volatile solid content basis mixed in the ratio $1: 1: 1)$ were subjected to digestion in separate anaerobic digesters. F/M ratio of 0.5 was maintained for this study. In the case of individual feeds, cow dung contributed to the maximum gas 


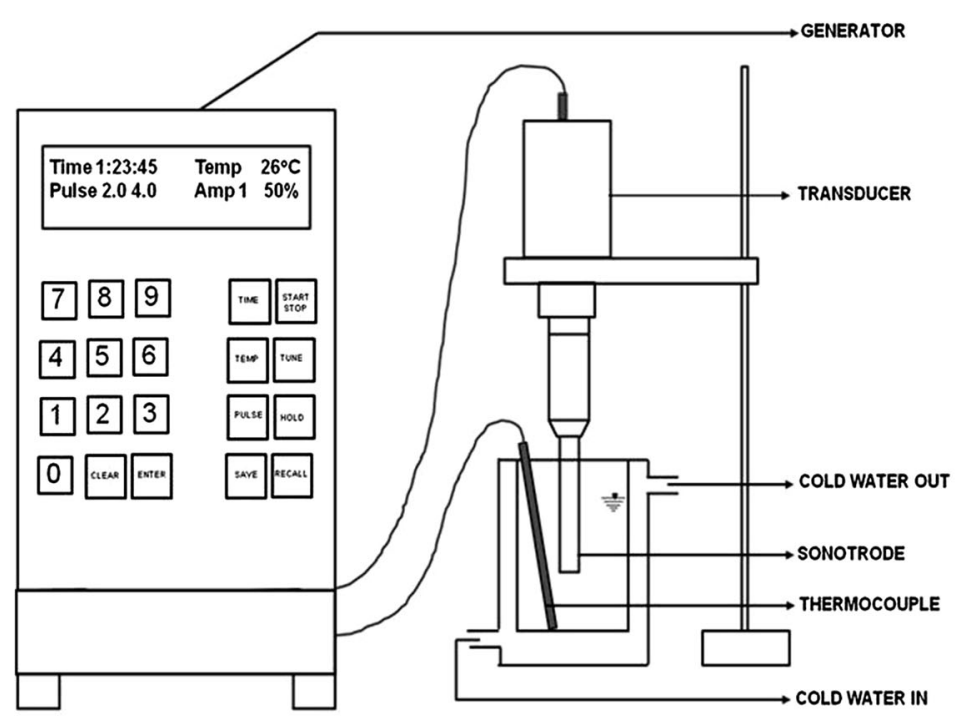

(a)

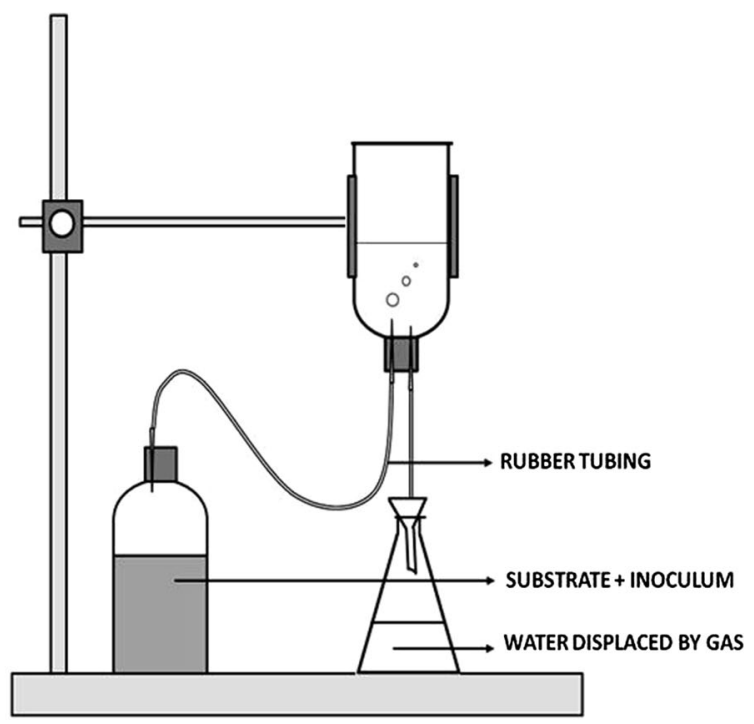

(b)

Fig. 1 Schematic of the a ultrasonic sludge disintegration set-up, b anaerobic co-digester set-up

production closely followed by primary sludge. Secondary sludge contributed to least gas production. The amount of gas produced is based on the relative amount of volatile solids present in the individual feeds. The mixed feed contributed more gas production compared to that of individual feeds. At the end of 45 days of retention time, gas production from mixed feed was about twice to that of secondary sludge. It was higher than individual gas productions of primary sludge and cow dung by 46 and $38 \%$, respectively. Cumulative gas production as a function of time for different feeds is shown in Fig. 2a. In case of mixed feed, the contributions of cow dung, primary sludge and secondary sludge for gas production are 38, 36 and $26 \%$, respectively. Based on the gas production profile, average rate of production using mixture of feeds, cow dung, primary sludge and secondary sludge is found to be $18,14,13$ and $10 \mathrm{~mL} /$ day, respectively. The above results suggest that cow dung is a suitable additive for anaerobic digestion of primary and secondary sludge derived from tannery effluent treatment plants.

\section{Selection of optimum F/M ratios}

Primary, secondary sludge and cow dung were mixed together based on the mass of volatile solids and was considered as feed for the digestion process. This feed was in turn mixed with micro-organisms in three different proportions $(\mathrm{F} / \mathrm{M}=0.3,0.5$ and 0.7$)$ to determine the optimum ratio. F/M ratio is an important operating variable that refers to mass of food supply to mass of microorganisms in the system. A too high F/M ratio can affect the process efficiency. On the other hand, too low ratio can lead to limited growth. Therefore, an optimum F/M ratio is required for efficient digestion. Based on the volume of gas production, the optimum feed to micro-organism ratio was found as 0.7 and this corresponds to a $\mathrm{C} / \mathrm{N}$ ratio of 18.2:1. This value is within the quoted range of 15:1 and 30:1 (for sludge co-digestion process) of previous work (Navaneethan 2007). Therefore, F/M ratio of 0.7 has been considered throughout the study. The results of CHN analysis are given in Table 2.

Selection of optimum pre-treatment time durations

In this study, both anaerobic biomass and the feed were individually subjected to ultrasonic pre-treatment for different treatment durations prior to anaerobic co-digestion. The optimum pre-treatment duration refers to the ultrasonic pre-treatment time of sludge and biomass that result in maximum volatile solids reduction cum gas production. Maximizing/enhancing gas production through ultrasonic pre-treatment has been the main aim of this work. The corresponding specific energy (energy required to achieve a certain degree of disintegration) is calculated using Eq. 1, and care has been taken to achieve better disintegration at specific energies as low as possible. The different time durations are presented in Table 3. Treatment time durations were found to affect the gas production. Better performances (in terms of volume of gas produced) were observed for the following treatment combinations viz., biomass $(3 \mathrm{~min})+$ feed $(5 \mathrm{~min})$, biomass $(5 \mathrm{~min})+$ feed $(5 \mathrm{~min})$, biomass $(5 \mathrm{~min})+$ feed $(3 \mathrm{~min})$. Other treatment combinations led to relatively low gas production. Hence, for clarity of presentation, data for the above-mentioned 

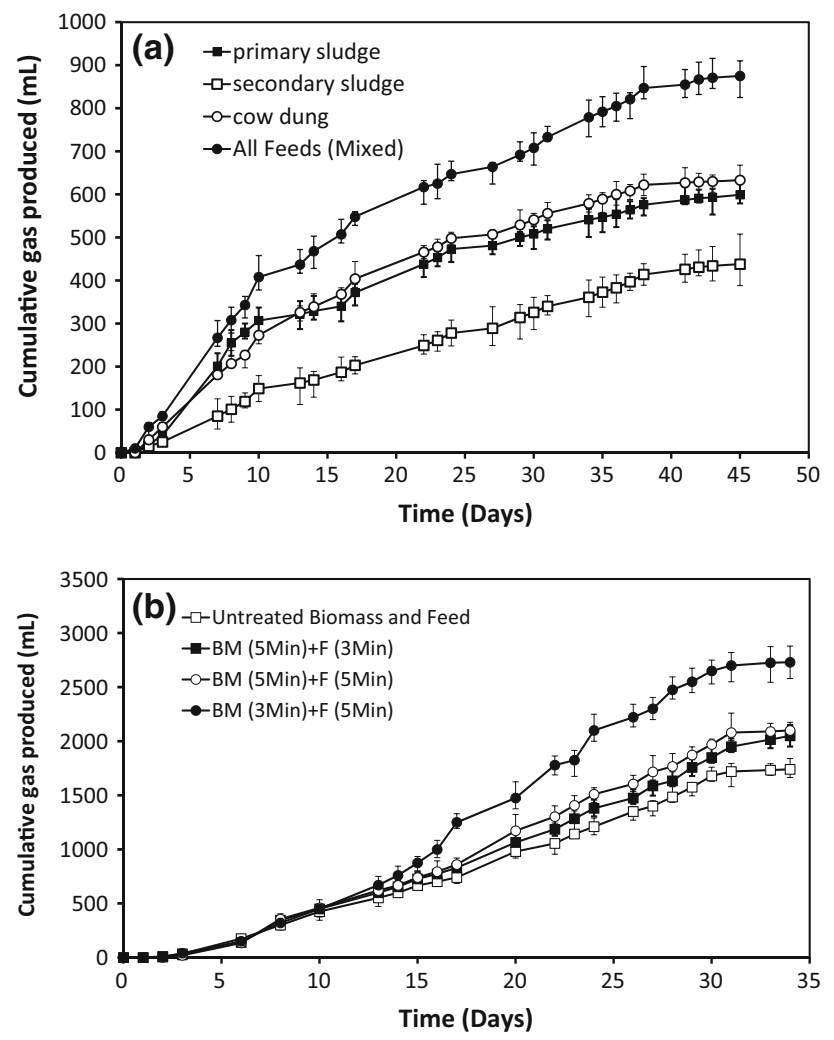

Fig. 2 a Influence of individual feed on gas production $(\mathrm{F} / \mathrm{M}=0.5)$, b pre-treatment combinations showing significant production of gas $[\mathrm{F} / \mathrm{M}=0.7$ (optimized) $]$

three combinations are presented in Fig. $2 \mathrm{~b}$ and compared with average gas production for untreated biomass and feed mixture. The average values of cumulative gas produced in 34 days for all treatment combinations are also provided in Table 3.

Out of several pre-treatment time combinations considered for feed and biomass, higher gas production has been realized for cases where feed was pre-treated for a maximum duration of $5 \mathrm{~min}$. This may be due to the effective release of organic materials from the feed debris by perpetual attack of large numbers of collapsing cavitation bubbles at higher treatment times. In addition, this could have led to the dispersion of aggregates and solubilization of particulate matter in the feed as reported in the literature (Foladori et al. 2007). Further increase in feed treatment time beyond $5 \mathrm{~min}$ would have improved gas production. However, higher energy requirement at longer treatment times was considered as a limiting factor.

As far as pre-treatment of biomass is concerned, relatively better gas production has been achieved for pretreatment time of $3 \mathrm{~min}$. This could be the optimum time when the disaggregation of flocs, cell damage and rupture occurred due to disintegration leading to release of microorganism in the bulk liquid. Lesser gas production
Table 2 Results of CHN analysis

\begin{tabular}{llll}
\hline F/M ratio & \% Carbon & \% Nitrogen & C:N ratio \\
\hline 0.3 & 30.19 & 2.52 & $12: 1$ \\
0.5 & 30.3 & 2.76 & $11: 1$ \\
0.7 & 29.4 & 1.62 & $18.2: 1$ \\
\hline
\end{tabular}

Table 3 Cumulative gas production (34 days) for all treatment combinations

\begin{tabular}{lll}
\hline $\begin{array}{l}\text { Biomass treatment } \\
\text { time }(\mathrm{min})\end{array}$ & $\begin{array}{l}\text { Feed treatment } \\
\text { time }(\mathrm{min})\end{array}$ & $\begin{array}{l}\text { Cumulative gas } \\
\text { produced }(\mathrm{mL})\end{array}$ \\
\hline 0 & 0 & 1,740 \\
1 & 1 & 1,795 \\
1 & 3 & 1,820 \\
1 & 5 & 1,964 \\
3 & 1 & 1,880 \\
3 & 3 & 1,914 \\
3 & 5 & 2,730 \\
5 & 1 & 1,870 \\
5 & 3 & 2,050 \\
5 & 5 & 2,100 \\
\hline
\end{tabular}

observed at treatment times less than 3 min may be due to ineffective disruption. Decline in gas production for treatments beyond $3 \mathrm{~min}$ could be attributed to the decrease in the number of live micro-organisms. Treatments exceeding a certain specific energy limit have been reported to bring disintegration and disruption of the micro-organisms leading to decrease in their number (Foladori et al. 2007).

Microcalorimetric analysis of the digestion process using anaerobic biomass

Figure 3 represents the normalized heat flow profile of untreated anaerobic biomass at $25{ }^{\circ} \mathrm{C}$ when enclosed in an ampoule over a period of 2 days. Normalized heat flow refers to the amount of heat energy released per unit mass of the biomass. Consistent profiles with a similar trend were obtained on repeating this experiment. These observations possibly throwlight on different stages of the anaerobic co-digestion process. Since the biomass was hermetically sealed in the ampoule and subjected to calorimetric studies, the micro-organisms start to utilize the limited amount of substrate available to them. Owing to technical difficulties, air inside the ampoules could not be flushed using nitrogen. The micro-organism present inside being facultative bacteria initially utilizes the oxygen trapped in the sealed ampoule. As oxygen is consumed continuously, it gets depleted over a period of time. This refers to aerobic process represented in Fig. 3. Due to the 

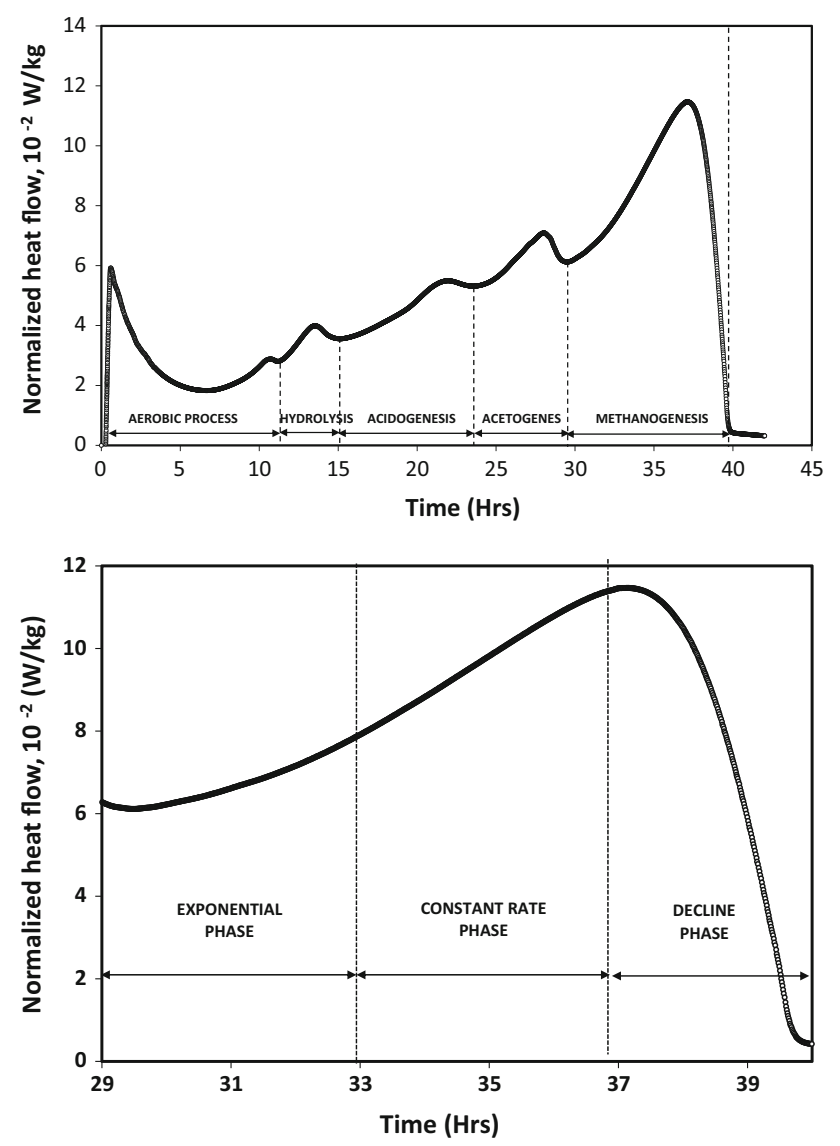

Fig. 3 Heat flow analysis of untreated anaerobic biomass (enclosed in ampoule) at $25^{\circ} \mathrm{C}$, magnified profile of methanogenesis step

absence of oxygen, probable anaerobic process could have been started with hydrolysis. It is during this step that the micro-organisms break the feedstock into simple sugars, amino acids and fatty acids. This is followed by acidogenesis when the components of previous step are broken down into volatile fatty acids, ammonia, carbon dioxide, hydrogen sulphide and other by-products. The molecules created are further digested by the microbes to produce acetic acid, carbon dioxide and hydrogen during the third step called acetogenesis. Microbes convert the intermediate products into methane, carbon dioxide and water, making up the majority of the gas output during the last step called methanogenesis. The heat released during each of these steps is shown in Fig. 3. After methanogenesis, the digestate is left with lesser number of microbes which eventually vanishes completely. Although different stages of anaerobic digestion process would occur simultaneously, the heat flow profile of the digestion process indicates a possible hypothesis that respective stages of the digestion sequence (viz., hydrolysis, acidogenesis, acetogenesis, methanogenesis) are predominant at their respective time intervals, while other stages also prevail during the process.
A close look at the methanogenesis step (Fig. 3) reveals three distinct regions in the process of gas generation reported elsewhere (Stronach et al. 1986). viz. exponential phase, linear phase and declining phase.

Microcalorimetric substantiation of ultrasonic pretreatment

Figure 4 shows the normalized heat flow profile of $3 \mathrm{~min}$ pre-treated anaerobic biomass in comparison with that of untreated anaerobic biomass described in Fig. 3. Similarity in the trend of heat flow profiles clearly validates the occurrence of different anaerobic stages in the pre-treated sample as well. Using Eq. 2, the heat energy released was calculated for both untreated and treated anaerobic biomass. Higher energy release was observed in treated sample $(16.3 \mathrm{~kJ} / \mathrm{kg})$ compared to that of untreated sample $(7.6 \mathrm{~kJ} / \mathrm{kg})$. Release of more energy in treated sample could be due to the increase in microbial maintenance energy requirements arising out of pre-treatment process. All these microcalorimetric observations clearly substantiate the increased maintenance energy requirements of micro-organisms due to ultrasonic pre-treatment.

\section{Disintegrability studies on feed}

Ultrasonic disintegration of sludge flocs has been reported to disrupt microbial cell walls and release soluble substances (Wang et al. 2005). This in turn can result in the increase of soluble chemical oxygen demand (SCOD) which can be determined by the method suggested by Mueller (2000). Figure 5 illustrates the change in SCOD with respect to ultrasonic specific energy. The SCOD release increased linearly up to $27 \%$ on supplying the specific energy $=15,000 \mathrm{~kJ} / \mathrm{kg}$. This specific energy corresponds to the treatment time of $5 \mathrm{~min}$. Additional $18 \%$ increase in SCOD release was observed for specific energy $=45,000 \mathrm{~kJ} / \mathrm{kg}$ (corresponding to treatment time of $15 \mathrm{~min}$ ). Further extension of disintegration time (up to $35 \mathrm{~min}$ ) led only to a marginal increase in SCOD release (i.e. $9 \%$ ). Therefore, it can be concluded that pre-treatment for $5 \mathrm{~min}$ is sufficient to treat the feed and still achieve a better SCOD release. This would require very less specific energy consumption. This is in accordance with the findings of $\mathrm{Chu}$ et al. (2002), who demonstrated that "weak" ultrasound pre-treatment greatly increased both the production rate and ultimate yield of methane.

Kinetic studies

Anaerobic digestion process has been expressed by a firstorder kinetic model by several researchers (Thangamani 


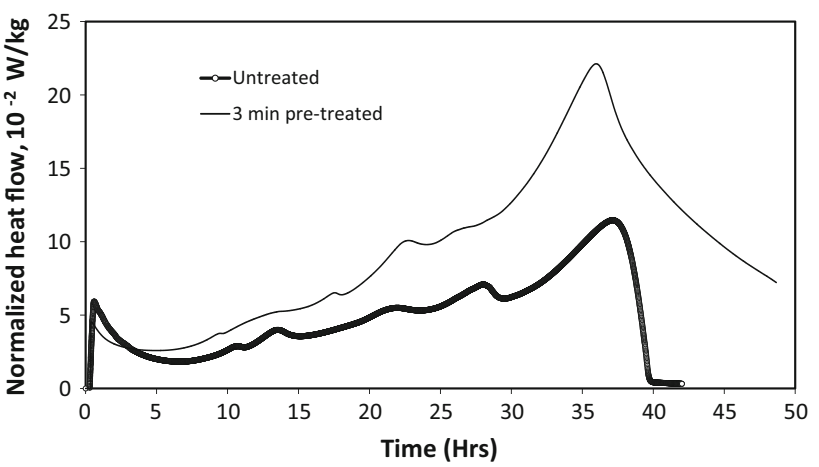

Fig. 4 Heat flow analysis of untreated and pre-treated anaerobic biomass

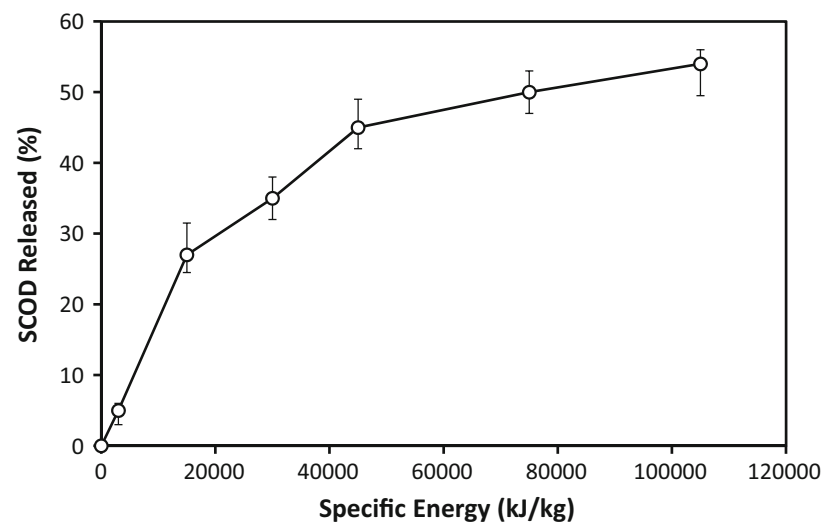

Fig. 5 Effect of ultrasonic disintegration on SCOD

et al. 2010; Mahmoud et al. 2004; Parker 2005). This model is based on the following two facts.

1. The rate of substrate conversion to biogas is directly proportional to the substrate concentration.

2. The volume of gas generated is proportional to the mass of the substrate destroyed.

These facts could be expressed in the form of equations as follows. $\frac{\mathrm{d} S}{\mathrm{~d} t}=-k S$

$Y=C V\left(S_{0}-S\right)$

where $k$ is the overall rate constant $\left(\right.$ day $\left.^{-1}\right), Y$ is cumulative gas production $(\mathrm{L}), C$ is yield constant $(\mathrm{L} / \mathrm{g})$ and $V$ is volume of reactor $(\mathrm{L})$.

Integration of (3) gives

$S=S_{0} \exp \left(-k\left(t-t_{0}\right)\right)$,

where $t_{0}$ is the lag time (days) and $t>t_{0}$

Substituting $S$ in (4) gives,

$Y=C V S_{0}\left[1-\exp \left(-k\left(t-t_{0}\right)\right)\right]$

Rearranging (5) gives,

$\ln \left(1-\frac{Y}{C V S_{0}}\right)=-k t+k t_{0}$

Yield constant, $C$ was calculated from the experimental data. A plot of $\ln \left(1-\frac{Y}{C V S_{0}}\right)$ versus time gave the overall rate constant " $k$ " and lag time " $t_{0}$ " which are presented in Table 4.

Modelling of gas production

Experimental gas production data obtained during the anaerobic digestion process were modelled using modified Gompertz equation ( $\mathrm{Li}$ et al. 2012; Uma Rani et al. 2012) given below.

$y=A \exp \left\{-\exp \left[\frac{\mu_{m} e}{A}\left(t_{0}-t\right)+1\right]\right\}$

where $y$ is the gas accumulation $\left(\mathrm{L} \mathrm{g}^{-1}\right), t$ is the time (days) of the digestion period. $A$ is the gas production potential (L $\left.\mathrm{g}^{-1}\right) \cdot \mu_{m}$ is the maximum gas production rate $\left(\mathrm{L} \mathrm{g}^{-1} \mathrm{~d}^{-1}\right)$, while $t_{0}$ is the lag time (days) and $e$ is equal to 2.7183 . The model parameters were estimated using a data analysis software and are given in Table 4.

Figure 6a shows the logarithmic plot of gas production. It can be observed from the slope of the plots that the

Table 4 Comparison of kinetic and model parameters for untreated and pre-treated samples after sludge retention time of 34 days

\begin{tabular}{lllll}
\hline Sample & Parameters & Experiment & $\begin{array}{l}\text { Modified } \\
\text { Gompertz model }\end{array}$ & $\begin{array}{l}\text { First-order } \\
\text { kinetic model }\end{array}$ \\
\hline Untreated & Gas production potential $\left[\mathrm{A}\left(\mathrm{L} \mathrm{g}^{-1}\right)\right]$ & 0.3833 & 0.5554 & - \\
& Maximum gas production rate $\left[\mu_{\mathrm{m}}\left(\mathrm{L} \mathrm{g}^{-1} \mathrm{day}^{-1}\right)\right]$ & 0.0143 & 0.0149 & - \\
& Lag time $\left[t_{0}(\right.$ days $\left.)\right]$ & 5.4 & 5.6 & 3 \\
& Rate constant $\left[k\left(\right.\right.$ day $\left.\left.^{-1}\right)\right]$ & - & - & 0.0042 \\
Pre-treated & Gas production potential $\left[\mathrm{A}\left(\mathrm{L} \mathrm{g}^{-1}\right)\right]$ & 0.4279 & 0.5443 & - \\
& Maximum gas production rate $\left[\mu_{\mathrm{m}}\left(\mathrm{L} \mathrm{g}^{-1}\right.\right.$ day $\left.\left.^{-1}\right)\right]$ & 0.02 & 0.019 & 3.8 \\
& Lag time $\left[t_{0}(\right.$ days $\left.)\right]$ & 7.1 & 7.8 & 0.0063 \\
\hline
\end{tabular}



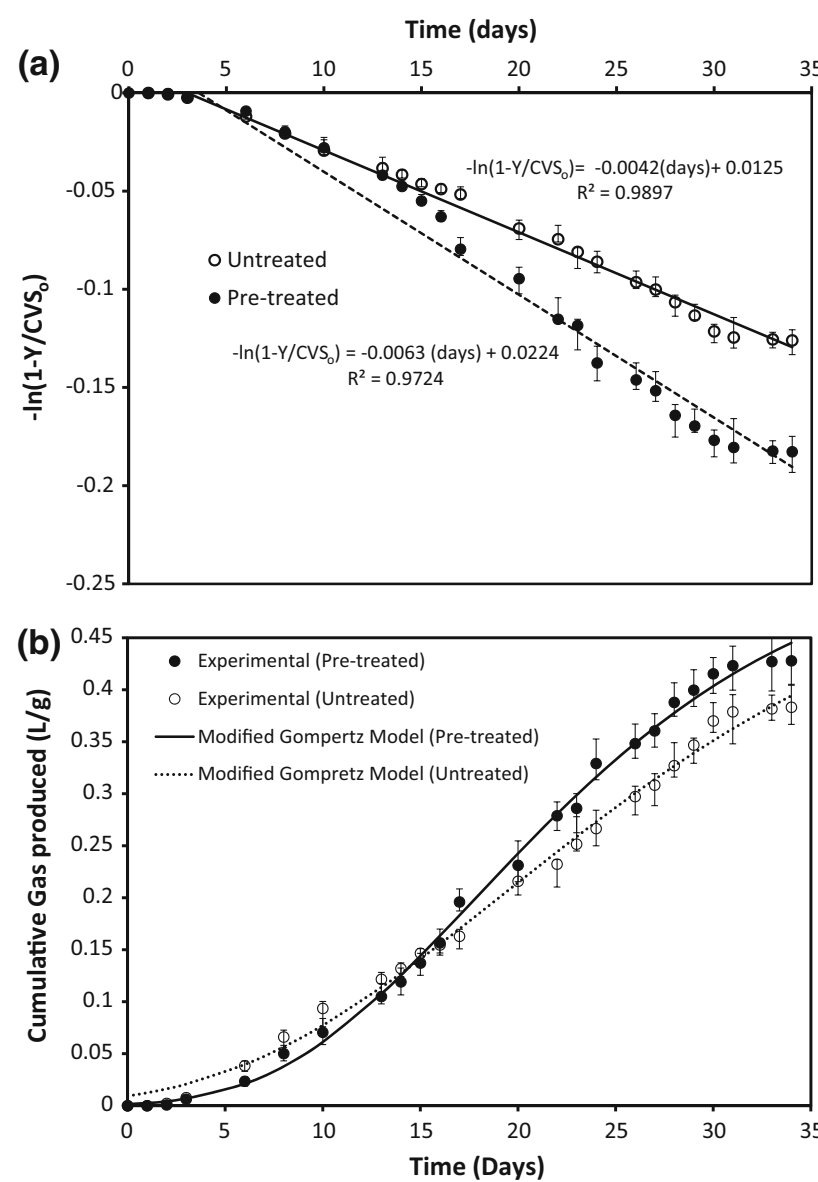

Fig. 6 a Logarithmic plot gas production and time, $\mathbf{b}$ comparison of experimental gas production with modified Gompertz model

digestion of ultrasonic pre-treated sample is 1.5 times faster than that of untreated sample. Pre-treated sample refers to the optimized combination of 3 min treated biomass together with $5 \mathrm{~min}$ treated feed. However, the lag time of pre-treated sample is about $20 \%$ higher than that of untreated sample. Soon after pre-treatment, the microorganisms are in a state of stress that they require additional time to recover and actually start the digestion process. This could be the reason for higher lag time of pretreated sample. Figure $6 \mathrm{~b}$ shows the comparison of experimental data with the gas production predicted by modified Gompertz model. The model parameters for the best fit are given in Table 4.

\section{Conclusion}

The present study investigated the anaerobic co-digestion of ultrasonic disintegrated feed and biomass, and the disintegration effect on biomass was substantiated by isothermal microcalorimetry. Ultrasonic pre-treatment on feed and biomass has been found to maximize gas production with minimum sludge retention time. Longer treatment time on feed may results still improved gas production, but higher mechanical energy input could be a limiting factor. Moderate treatment of biomass ( $3 \mathrm{~min}$ ) yielded better gas production, and when it is less or higher than $3 \mathrm{~min}$, there is a retard in gas production. A microcalorimetric heat flow analysis of the anaerobic digestion process indicates the possible hypothesis that the respective stages of the digestion sequence are predominant at their respective time interval. It is observed that more heat energy released by pre-treated biomass sample compared to untreated sample, due to increase in cellular maintenance energy requirements. Kinetic analysis showed that the overall rate constant of ultrasonic pre-treated sample is 1.5 times higher than that of untreated sample. Modified Gompertz model fitted well with the experimental data, and model parameters were evaluated.

Ultrasonic pre-treatment of sludge and biomass could be an economically viable and technically feasible option for enhanced digestion. However, a thorough analysis of the energy requirements and cost economics should be made based on pilot scale studies.

Acknowledgments The authors wish to thank CSIR-ZERIS (CSC 0103-WP 28) project for funding this research work. Thanks are also due to Prof. Dr. A. B. Mandal, Director CSIR-CLRI for his keen interest in this work and Late Mr. F. Chandrasekaran, Technical officer, operator Microcalorimetry (TAM III) for his effort and useful discussions.

\section{References}

Alklint C, Wadsö L, Sjöholm I (2004) Effects of modified atmosphere on shelf-life of carrot juice. Food Control 15(2):131-137

Alvarez JM, Mace S, Llabres P (2000) Anaerobic digestion of organic solid wastes. An overview of research achievements and perspectives. Bioresourc Technol 74:3-16

Amani T, Nosrati M, Sreekrishnan TR (2011) A precise experimental study on key dissimilarities between mesophilic and thermophilic anaerobic digestion of waste activated sludge. Int $\mathrm{J}$ Environ Res 5(2):333-342

APHA (1998) Standard methods for the examination of water and wastewater. American Public Health Association, Washington

Appels L, Baeyens J, Degreve J, Dewil R (2008) Principles and potential of the anaerobic digestion of waste activated sludge. Prog Energy Combust 34:755-781

Balakameswari KS, Kalyanaraman C, Thanasekaran K (2010) Effect of ozonation and ultrasonication pre-treatment processes on codigestion of tannery solid wastes. Clean Techn Environ Policy 13(3):517-5250. doi:10.1007/s10098-010-0334-0

Battley E (1987) Energetics of microbial growth. Wiley, New York

Braguglia CM, Gagliano MC, Rossetti S (2012) High frequency ultrasound pre-treatment for sludge anaerobic digestion: effect on floc structure and microbial population. Bioresourc Technol 110:43-49

Carrère H, Dumas C, Battimelli A, Batstone DJ, Delgenès JP, Steyer JP, Ferrer I (2010) Pre-treatment methods to improve sludge anaerobic degradability: a review. J Hazard Mater 183(1-3):1-15 
Chu CP, Lee DJ, You CS, Tay JH (2002) Weak ultrasonic pretreatment on anaerobic digestion of flocculated activated biosolids. Water Res 36:2681-2688

Deublein D, Steinhauser A (2008) Biogas from waste and renewable resources: an introduction. Wiley- $\mathrm{VCH}$, Weinheim

Foladori P, Laura B, Gianni A, Giuliano Z (2007) Effects of sonication on bacteria viability in wastewater treatment plants evaluated by flow cytometry-fecal indicators, wastewater and activated sludge. Water Res 41(1):235-243

Gerardi MH (2003) The microbiology of anaerobic digesters. Wiley, Somerset NJ

Gustafsson L (1991) Microbiological calorimetry. Thermochim Acta 193:145-171

Itodo IN, Lucas EB, Kucha EI (1992) The effect of media material and its quality on biogas yield. Nigerian J Renew Energy 3(1-2):45-49

Kavitha S, Jayashree C, Adish Kumar S, Yeom IT, Rajesh Banu J (2014) The enhancement of anaerobic biodegradability of waste activated sludge by surfactant mediated biological pretreatment. Bioresour Technol 168:159-166

Khalid A, Arshad M, Anjum M, Mahmood T, Dawson L (2011) The anaerobic digestion of solid organic waste-review. Waste Manage 31:1737-1744. doi:10.1016/j.wasman.2011.03.021

Lakshmi MV, Merrylin J, Kavitha S, Adish Kumar S, Rajesh Banu J, Yeom IT (2014) Solubilization of municipal sewage waste activated sludge by novel lytic bacterial strains. Environ Sci Pollut Res J 21(4):2733-2743

Li L, Kong X, Yang F, Li D, Yuan Z, Sun Y (2012) Biogas production potential and kinetics of microwave and conventional thermal pre-treatment of grass. Appl Biochem Biotech 166(5):1183-1191

Lim JW, Wang JY (2013) Enhanced hydrolysis and methane yield by applying micro-aeration pre-treatment to the anaerobic codigestion of brown water and food waste. Waste Manage 33(4):813-819

Lin Y, Wang D, Wu S, Wang C (2009) Alkali pre-treatment enhances biogas production in the anaerobic digestion of pulp and paper sludge. J Hazard Mater 170(1):366-373

Mahmoud N, Zeeman G, Gijzen HJ, Lettinga G (2004) Anaerobic stabilisation and conversion of biopolymers in primary sludgeeffect of temperature and sludge retention time. Water Res 38:983-991

Merrylin S, Adish Kumar S, Kaliappan S, Yeom IT, Rajesh Banu J (2013) Biological pretreatment of non-flocculated sludge augments the biogas production in the anaerobic digestion of the pretreated waste activated sludge. Environ Technol 34(13-16):2113-2123

Mueller J (2000) Disintegration as a key-step in sewage sludge treatment. Water Sci Technol 41(8):123-130

Nagai H, Sato S, Takahashi M, Kawakami S, Choeisai PK, Syutsubo S, Ohashi A, Yamaguchi T (2012) Rubber and methane recovery from deproteinized natural rubber wastewater by coagulation pre-treatment and anaerobic treatment hatamoto. Int $\mathrm{J}$ Environ Res 6(3):577-584

Navaneethan N (2007) Anaerobic digestion of waste activated sludge with ultrasonic pre-treatment, MS dissertation thesis. Asian Institute of Technology, School of Environment, Resources and Development, Thailand

NEERI Phase I report (1997) Wastewater management in cluster of tanneries in Tamil Nadu, National Environmental Engineering Research Institute (NEERI), Nagpur, India

Parker WJ (2005) Application of the ADM1 model to advanced anaerobic digestion. Bioresour Technol 96:1832-1842
Pavlostathis SG, Gossett JM (1986) A kinetic model for anaerobic digestion of biological sludge. Biotechnol Bioeng 28(10): $1519-1530$

Safari E, Jalili Ghazizade M, Shokouh A, Nabi Bidhendi GhR (2011) Anaerobic removal of COD from High strength fresh and partially stabilized leachates and application of multi stage kinetic model. Int J Environ Res 5(2):255-270

Saravanabhavan S, Thanikaivelan P, Raghavarao J, Nair BU, Ramasami $\mathrm{T}$ (2004) Natural leathers from natural materials: progressing toward a new arena in leather processing. Environ Sci Technol 38:871-879. doi:10.1021/es034554o

Selvamurugan M, Doraisamy P, Maheswari M, Nandakumar NB (2012) Comparative study on startup performance of UAHR and UASB reactors in anaerobic treatment of distillery spentwash. Int J Environ Res 6(1):235-244

Stronach SM, Rudd T, Lester JN (1986) Anaerobic digestion process in industrial wastewater treatment, biotechnology monographs, vol 2. Springer, Berlin

Thangamani A, Suseela R, Ramanujam RA (2010) Anaerobic codigestion of hazardous tannery solid waste and primary sludge: biodegradation kinetics and metabolite analysis. Clean Techn Environ Policy 12:517-524

Tiehm A, Nickel K, Zellhorn M, Neis U (2001) Ultrasonic waste activated sludge disintegration for improving anaerobic stabilization. Water Res 35(8):2003-2009

Uan DK, Yeom IT, Arulazhagan P, Rajesh Banu J (2013) Effects of sludge pretreatment on sludge reduction in a lab-scale anaerobic/ anoxic/oxic system treating domestic wastewater. Int J Environ Sci Technol 10(3):495-502

Uma Rani R, Kaliappan S, Adish Kumar S, Rajesh Banu J (2012) Combined treatment of alkaline and disperser for improving solubilization and anaerobic biodegradability of dairy waste activated sludge. Bioresour Technol 126:107-116

Uma Rani R, Adish Kumar S, Kaliappan S, Yeom IT, Rajesh Banu J (2013) Impacts of microwave pretreatments on the semicontinuous anaerobic digestion of dairy waste activated sludge. Waste Manag 33(5):1119-1127

Uma Rani R, Adish Kumar S, Kaliappan S, Yeom IT, Rajesh Banu J (2014) Enhancing the anaerobic digestion potential of dairy waste activated sludge by two step sono-alkalization pretreatment. Ultrason Sonochem 21(3):1065-1074

Wang Q, Kuninobu M, Kakimoto K, Ogawa HI, Kato Y (1999) Upgrading of anaerobic digestion of waste activated sludge by ultrasonic pre-treatment. Bioresource Technol 68(3):309-313

Wang F, Wang Y, Ji M (2005) Mechanisms and kinetics models for ultrasonic waste activated sludge disintegration. J Hazard Mater 123:145-150

Weemaes MPJ, Verstraete WH (1998) Evaluation of current wet sludge disintegration techniques: a review. J Chem Technol Biotechnol 73:83-92. doi:10.1002/(SICI)1097-4660(1998100) 73:2<83:AID-JCTB932>3.0.CO;2-2

Weemaes M, Grootaerd H, Simoens F, Verstraete W (2000) Anaerobic digestion of ozonized biosolids. Water Res 34(8): 2330-2336

Zhang S, Zhang P, Zhang G, Fan J, Zhang Y (2012) Enhancement of anaerobic sludge digestion by high-pressure homogenization. BioresourceTechnol 118:496-501. doi:10.1016/j.biortech.2012. 05.089

Zielewicz E, Sorys P (2008) Ultrasonic disintegration of excess sludge before anaerobic stabilization. Archit Civil Eng Environ $1: 147-154$ 